\title{
Satellite-measured phytoplankton variability in the Gulf of Maine
}

\author{
Andrew C. Thomas*, David W. Townsend, Ryan Weatherbee \\ School of Marine Sciences, University of Maine, 5741 Libby Hall, Orono ME 04469-5741, USA
}

Received 26 June 2002; accepted 14 April 2003

\begin{abstract}
The first 4 years of SeaWiFS ocean color data (September 1997-August 2001) provide the first synoptic quantification of seasonal and interannual phytoplankton chlorophyll variability in the Gulf of Maine. Climatological monthly means show spatial patterns associated with the annual cycle. Concentrations are elevated throughout the year in coastal regions and over shallow banks (Georges Bank, Nantucket Shoals and Browns Bank) with a spring and fall bloom superimposed. Over deeper basins and the Scotia Shelf, a canonical North Atlantic seasonal cycle is present with low $\left(<1 \mathrm{mg} \mathrm{m}^{-3}\right.$ ) winter (December-February) concentrations, an annual maximum in March-April $\left(>2 \mathrm{mg} \mathrm{m}^{-3}\right)$, reduced concentrations in summer and a fall bloom beginning as early as September in Jordan Basin but in OctoberNovember over other regions. Strong interannual variability over the 4-year time series shows the climatological seasonal features are often a biased picture of both timing and magnitude. The clearest interannual signal is of reduced chlorophyll concentrations throughout 1998, including weak spring and fall blooms. A connection between low concentrations in 1998 and local wind forcing is not evident. However, the low concentrations are coincident with negative anomalies in satellite surface temperature fields and follow the intrusion of relatively cold, low salinity slope water into the Northeast Channel which previous authors have argued is linked to changes in Labrador slope water transport induced by the North Atlantic Oscillation. Reduced concentrations in 1998 are consistent with both lower nitrate/nitrite concentrations in the intruding water as well as reduced subsurface stratification which would delay or reduce the onset of the spring bloom.
\end{abstract}

(C) 2003 Elsevier Ltd. All rights reserved.

Keywords: Phytoplankton; Gulf of Maine; Satellite ocean color; Seasonal variability; Interannual variability; North Atlantic oscillation

\section{Introduction}

Bathymetry, coupled with differences in the relative strength and/or seasonality of advection, tidal mixing and stratification lead to a strong

\footnotetext{
*Corresponding author.

E-mail address: thomas@maine.edu (A.C. Thomas).
}

spatial heterogeneity in the oceanographic environment that phytoplankton encounter in the Gulf of Maine. Specific regions of the Gulf of Maine (Fig. 1) are some of the more heavily studied coastal regions of the ocean (e.g. Georges Bank). Previous examinations of chlorophyll spatial variability in the Gulf are based on data collected (a) episodically and at coarse spatial resolution by 


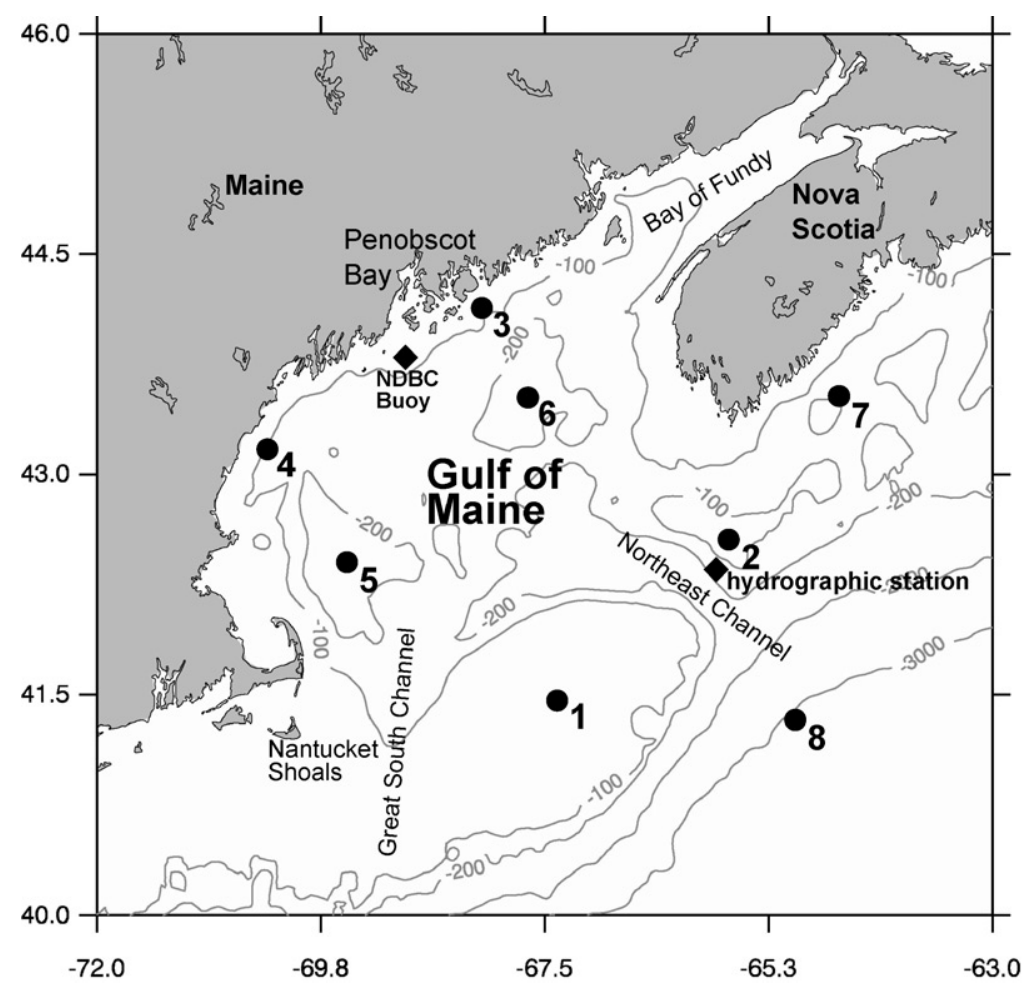

Fig. 1. Gulf of Maine study area showing bathymetry, major geographic features and 8 locations at which time series were extracted from the image time series. These locations are numbered: (1) Georges Bank, (2) Browns Bank, (3) Eastern Maine Coastal Current (EMCC), (4) Western Maine Coastal Current (WMCC), (5) Wilkinson Basin, (6) Jordan Basin, (7) Scotian Shelf and (8) Offshore. The buoy location at which wind data were measured and the location of a hydrographic station in the Northeast Channel are also shown.

specific programs (e.g. O'Reilly and Busch, 1984; O'Reilly et al., 1987)] providing general overviews or (b) at higher spatial resolution targeting specific regions, time periods and/or processes (e.g. Fournier et al., 1984a, b; Horne et al., 1989; Townsend and Pettigrew, 1997; Townsend et al., 2001; Townsend and Thomas, 2001). Cruises, however, provide either non-synoptic, coarse resolution realizations of overall phytoplankton patterns or detailed but time and site specific views of localized features and processes. Direct comparisons, relationships and possible interactions between subregions within the Gulf, as well as the relative timing and nature of response to seasonal and interannual forcing remain poorly quantified. Systematic analyses of synoptic spatial/temporal variability of phytoplankton have awaited the availability of a consistent satellite ocean color time series.
Examination of the seasonal progression of phytoplankton concentrations and their spatial distributions in the Gulf of Maine have their foundation in the early works of Henry Bigelow and later, Gordon Riley. Riley (1941) measured a strong spring (April) maximum in phytoplankton biomass over Georges Bank and a minimum in winter (January). He reviews earlier studies (Riley, 1947) noting that the spring bloom tends to begin earliest in shallow coastal areas (January-March), later over offshore banks (March-April) and latest over deeper basins and the shelf edge (April-May). More recently, O'Reilly et al. (1987) show that general spatial distributions of phytoplankton concentration in the Gulf of Maine have a strong inverse relationship with bathymetry. Vertical stability within the deeper basins of the Gulf of Maine, and its influence on phytoplankton dynamics, exhibits a seasonal cycle similar to that 
observed offshore in the North Atlantic; minimum in winter, maximum in summer. Georges Bank, however, remains relatively well vertically mixed throughout the year, eliminating much of the influence of stratification on the timing of phytoplankton seasonality. Jossi and Smith $(1989,1990)$ show the seasonal variability in phytoplankton color measured by the Continuous Plankton Recorder along a transect between Boston and southwest Nova Scotia in 1988 and 1989. These data, which sample only the larger phytoplankton, show (1) the spring bloom develops earliest in Massachusetts Bay and (2) strong variability between the 2 years in both the timing and position (along their transect) of the spring bloom. This spatial pattern is consistent with earlier work (Bigelow, 1927) which shows the western portion of the Gulf as the most vertically stable and Georges Bank, the Maine Coastal Current and the southwest Scotian Shelf as the least vertically stable. The two-dimensional spatial ramifications of the pattern presented by Jossi and Smith (1989, 1990) and especially its variability remain poorly quantified. On the Scotian Shelf, Herman et al. (1991) show that by May in 1985 the spring bloom was over, surface concentrations were $<1.0 \mathrm{mg} \mathrm{m}^{-3}$, and a subsurface chlorophyll maximum at $40 \mathrm{~m}$ was well developed, persisting into October. In this region, the spring bloom typically occurs in late March (Perry et al., 1989) with interannual variability in both timing and magnitude controlled by hydrographically controlled differences in vertical stability. Fournier et al. (1984b) show mid-summer chlorophyll concentrations of $\sim 5.0 \mathrm{mg} \mathrm{m}^{-3}$ at southern Scotian Shelf frontal zones separating cold, nutrient-rich surface water from more stratified conditions off the shelf. Fieldwork has shown that coupling between hydrography and nutrient transport in eastern Gulf of Maine has a significant influence on resultant biological patterns (Townsend et al., 1987; Brooks and Townsend, 1989) and these authors point out the strong temporal variability of patterns evident in individual SST satellite scenes. O'Reilly et al. (1987) and O'Reilly and Zetlin (1996) present a climatological (1977-1982 and 1977-1988, respectively) seasonal cycle of chlorophyll in northeast US coastal waters calcu- lated from in situ (MARMAP) data. These data show that over Georges Bank, lowest concentrations are found in mid-winter and mid-summer. Concentrations in the Maine Coastal Current are higher than those in the central Gulf of Maine over deeper basins throughout the year except in late fall.

A series of surface temperature and Coastal Zone Color Scanner (CZCS) ocean color satellite images from 1979 (Yentsch and Garfield, 1981) show the strong spatial relationship between phytoplankton pigment concentration and surface temperature in the Gulf of Maine. The authors point out the similarity of these patterns to those of vertical stability described many years earlier by Bigelow (1927) and quantified later by Garrett et al. (1978) using the Simpson and Hunter (1974) model of tidal mixing and stratification. A statistical analysis of the spatial and temporal variance in 36 reduced resolution CZCS images over $\sim 4$ months in 1979 by Eslinger et al. (1989) over northeastern North American waters includes results for the Gulf of Maine. Examination of their figures suggests that, at least in 1979, the timing of pigment concentration increases over Georges Bank were out of phase with those in the western Gulf of Maine. Over the deeper basins of the southern Gulf of Maine, episodic increases in pigment concentration took place in March and April, followed by larger increases in June. Over Georges Bank, March imagery showed smaller increases followed by a large increase in April. Examination of the full 7.5-year time series of CZCS imagery at the shelf break (Ryan et al., 1999) documents a strong annual enhancement of spring pigment over the southern flank of Georges Bank associated with the shelf break front. Yoder et al. (2001) use the same data to show that in US Atlantic coastal and shelf waters, a simple seasonal cycle, maximum in winter, dominates chlorophyll variability. Their analysis does not include the interior of Gulf of Maine, but includes Georges Bank that they show has poor temporal correlation with shelf regions farther south. They do, however, present CZCS climatological composite images of the 12 month seasonal cycle which include the Gulf of Maine. Over the deeper basins, these show low concentrations in winter and 
mid-summer, with maxima in April and September-October. Over Georges Bank and in nearshore waters, their images show a January maximum that they report as characteristic of the whole US eastern seaboard. Recently, Yoder et al. (2002) compared seasonal cycles in SeaWiFS, CZCS and in situ data sets to show that mean chlorophyll concentrations over the northeast shelf $(\sim 35$ $45^{\circ} \mathrm{N}$ ) peak in March-April and again in OctoberNovember. They show an overall inverse relationship between seasonal chlorophyll and surface temperature patterns.

Residual circulation in the Gulf of Maine is relatively well described. Spatial patterns are strongly influenced by bathymetry and tidal mixing (Garrett et al., 1978). A schematic based on drifter tracks and hydrography (Xue et al., 2000) shows cyclonic flow around the entire Gulf and anticyclonic flow around Georges Bank. The amplitude and timing of this pattern are modulated by differences induced by vertical mixing over shallow bathymetry, stratification induced by freshwater in the coastal zone and residual circulation. Within this pattern, two distinct cyclonic gyres are apparent over Jordan and Georges Basins. The vernal circulation in the Gulf of Maine inferred from June 1983 hydrography surveys (Brooks, 1985) shows separated cyclonic flows around all three major basins. A coastal current, usually divided into the Eastern Maine Coastal Current (EMCC) and the Western Maine Coastal Current (WMCC), makes up the nearshore portion of the cyclonic flow with a branch of the EMCC often observed turning offshore into the interior of the Gulf in the vicinity of Penobscot Bay (Brooks and Townsend, 1989; Pettigrew et al., 1998). Surface thermal signatures of both the vertical mixing and residual circulation are reflected in patterns evident in satellite surface temperature data (Bisagni et al., 1996, 2001).

Our goal is to provide a quantification of the synoptic mean seasonal cycle and interannual variability evident in the first 4 years (September 1997-August 2001) of SeaWiFS chlorophyll measurements for the Gulf of Maine. In Section 2 we describe the data sets and methodology and in Section 3 we present results of the analysis of seasonal and interannual variability. Time and space patterns evident in these results are discussed in Section 4 in comparison to concurrent wind forcing, sea surface temperature (SST) and available hydrographic data. Section 5 provides a summary and brief conclusions.

\section{Data and methods}

Daily Level 1a data from SeaWiFS passes covering the Gulf of Maine for the period September 1997-August 2001 were obtained from the NASA Goddard Space Flight Center DAAC, processed to Level 2 chlorophyll (OC4) using standard global coefficients (O'Reilly et al., 1998) and flags optimized for the study area (SEADAS defaults plus low nLw 555 and straylight set to masks) and then remapped to a standard mercator projection at $1.1 \mathrm{~km}$ resolution. All images were reviewed manually and those with obvious errors in atmospheric correction, cloud flagging and/or chlorophyll retrievals (typically these were cloudy images with less than $10 \%$ cloud-free ocean) were flagged as invalid. In addition, days with multiple passes inevitably included one in which the study area was nearest nadir and chlorophyll patterns and concentrations were well correlated to those of immediately preceding and succeeding days of single high-elevation passes, and another with larger imaging angle geometry in which both concentrations and patterns were suspect. In such cases, the latter was discarded from the time series. This resulted in a time series of daily scenes over the 4 years with gaps in time and space of actual chlorophyll retrievals due to clouds. A morphological dilation of 1 pixel was applied to cloud and land flags in each daily image, followed by a $5 \times 5$ pixel median filtering in the spatial domain to reduce noise and fill small gaps. Daily scenes were then formed into 8-day and monthly composites by calendar day in each year.

Both extreme aerosol variability and in-water color constituents that often create Case 2 conditions present challenges for ocean color work in the Gulf of Maine that have yet to be fully overcome. The most current reprocessing coefficients, the removal of obviously problematic 
images and space/time filtering, however, produce a time series in which relative patterns appear both internally consistent and consistent with in situ fields from both literature and concurrent data. Comparisons of 3 years (1999-2001) of exact time/ space match-up summer log-transformed in situ chlorophyll to log-SeaWiFS chlorophyll have an $r^{2}$ of $0.55(n=305)$ and a slope of 0.72 (B. Balch, Bigelow Laboratory, personal communication). In general over the Gulf of Maine, the current SeaWiFS processing (3rd reprocessing) overestimates chlorophyll at low concentrations and underestimates at high concentrations with the hinge occurring at $\sim 2.0 \mathrm{mg} \mathrm{m}^{-3}$. Although this limits our ability to interpret actual concentrations and reduces the strength of time and space gradients, we focus our analysis and discussion on the temporal and spatial variability of relative patterns that appear realistic. These data still provide our first view of synoptic seasonal and interannual variability in this region.

SST fields from the NOAA Advanced Very High Resolution Radiometers (AVHRR) are received directly at the University of Maine Satellite Oceanography Data Laboratory 4-6 times each day. These data are navigated, processed to SST using standard NOAA day and night coefficients, cloud and land masked, remapped to the same projection as the SeaWiFS data and archived. The 120-150 images available in each month were formed into monthly composites over the study period using similar dilation and time/space filtering protocols as those used to form chlorophyll composites.

\section{Results}

\subsection{Seasonal variability}

Fig. 2 presents patterns of the climatological annual cycle of chlorophyll concentration in the Gulf of Maine as a monthly series. Inspection reveals generalized seasonal and spatial patterns consistent with chlorophyll fields contoured from more sparsely sampled in situ data (e.g. Townsend and Spinrad, 1986; O'Reilly and Zetlin, 1996; Townsend et al., 2001), consistent with the representative seasonal months presented by Yoder et al. (2002) and reveals persistent smaller-scale features not evident in previous analyses. Concentrations are elevated along the coastal margin, in the Bay of Fundy and over Georges Bank and Nantucket Shoals throughout the year. An unknown portion of this signal is undoubtedly contributed by resuspended sediment and/or colored dissolved organic matter.

Lowest concentrations are present in summer in the furthest southeast corner of the study area, off the continental shelf (Fig. 1) in oligotrophic water associated with the Gulf Stream and in winter in the Gulf. Within the Gulf of Maine and over the southern Scotian Shelf, concentrations are low in winter (December-February), increase in MarchMay during the spring bloom and then decrease in mid-summer (June-July). In late summer and fall (August-November) concentrations again increase during a fall bloom, before decreasing in winter. Spatial patterns of this seasonality reflect bathymetry (Fig. 1) and residual circulation (Brooks, 1985; Pettigrew et al., 1998). Concentrations over Georges Bank, although elevated throughout the year, weaken in winter and late summer. Lower concentrations in the Great South Channel and over the Northeast Channel clearly separate the elevated concentrations on Georges Bank from those over Nantucket Shoals and those over the Browns Bank/Scotian Shelf region. Elevated concentrations are also evident over Browns Bank during the June-October period. Both the spring and fall blooms appear strongest in the western portion of the Gulf over Wilkinson Basin. Summer concentrations over the deeper basins within the Gulf of Maine (Wilkinson, Georges and Jordan Basins, Fig. 1) are relatively low. Elevated chlorophyll concentrations extend offshore into more oligotrophic portions of the central Gulf of Maine from the coastal region immediately south of Penobscot Bay during spring-summer. This region is where colder, nutrient-rich surface waters of the Eastern Maine Coastal Current turn cyclonically offshore (Townsend et al., 1987; Bisagni et al., 1996; Pettigrew et al., 1998). Relatively low concentrations are evident over the deeper basin at the mouth of the Bay of Fundy from October through March. 

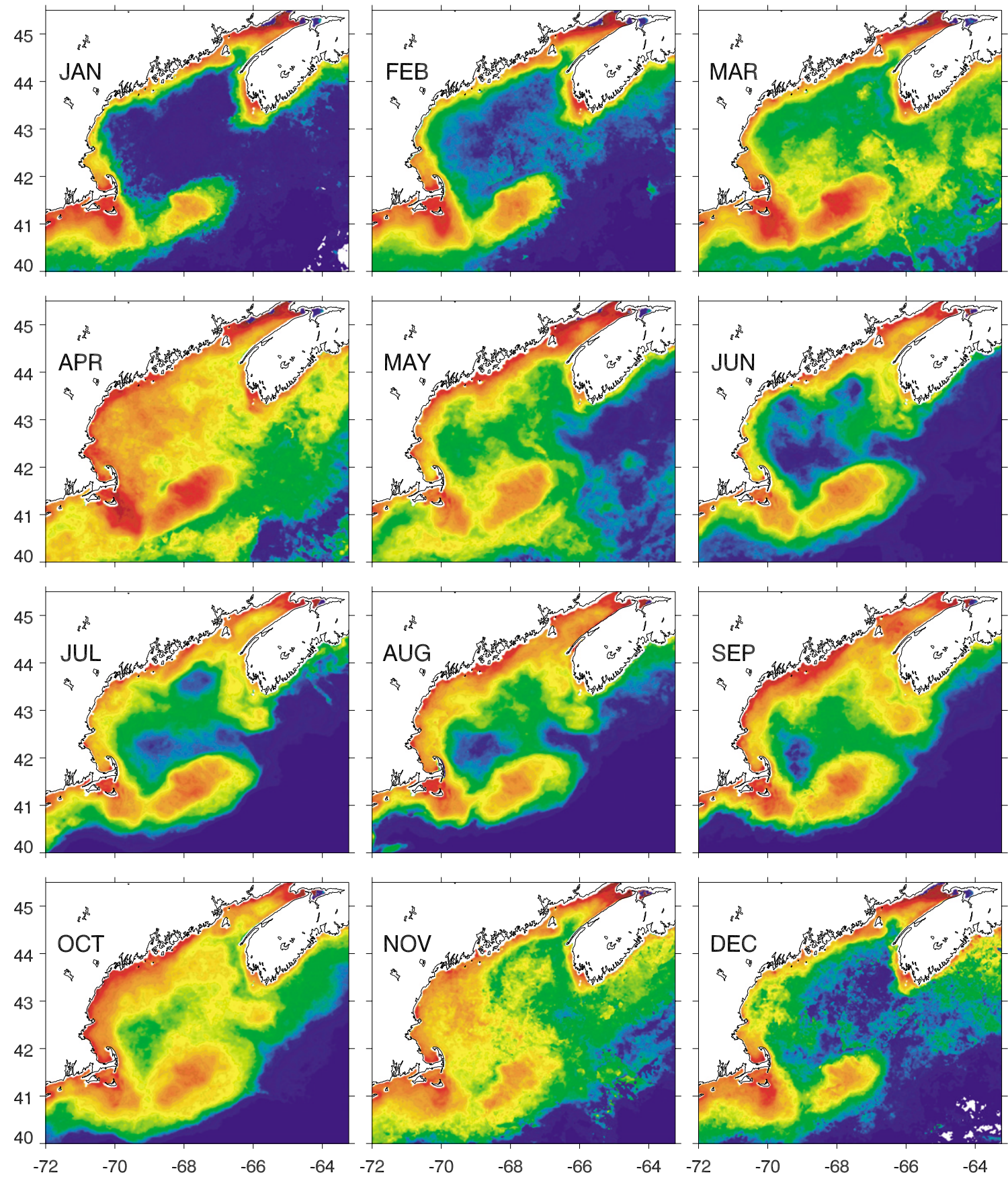

$\mathrm{mg} \cdot \mathrm{m}^{-3}$

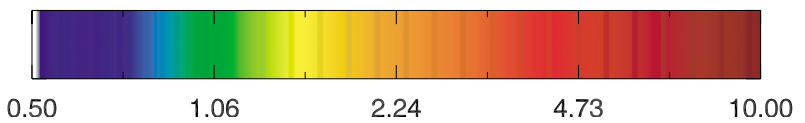



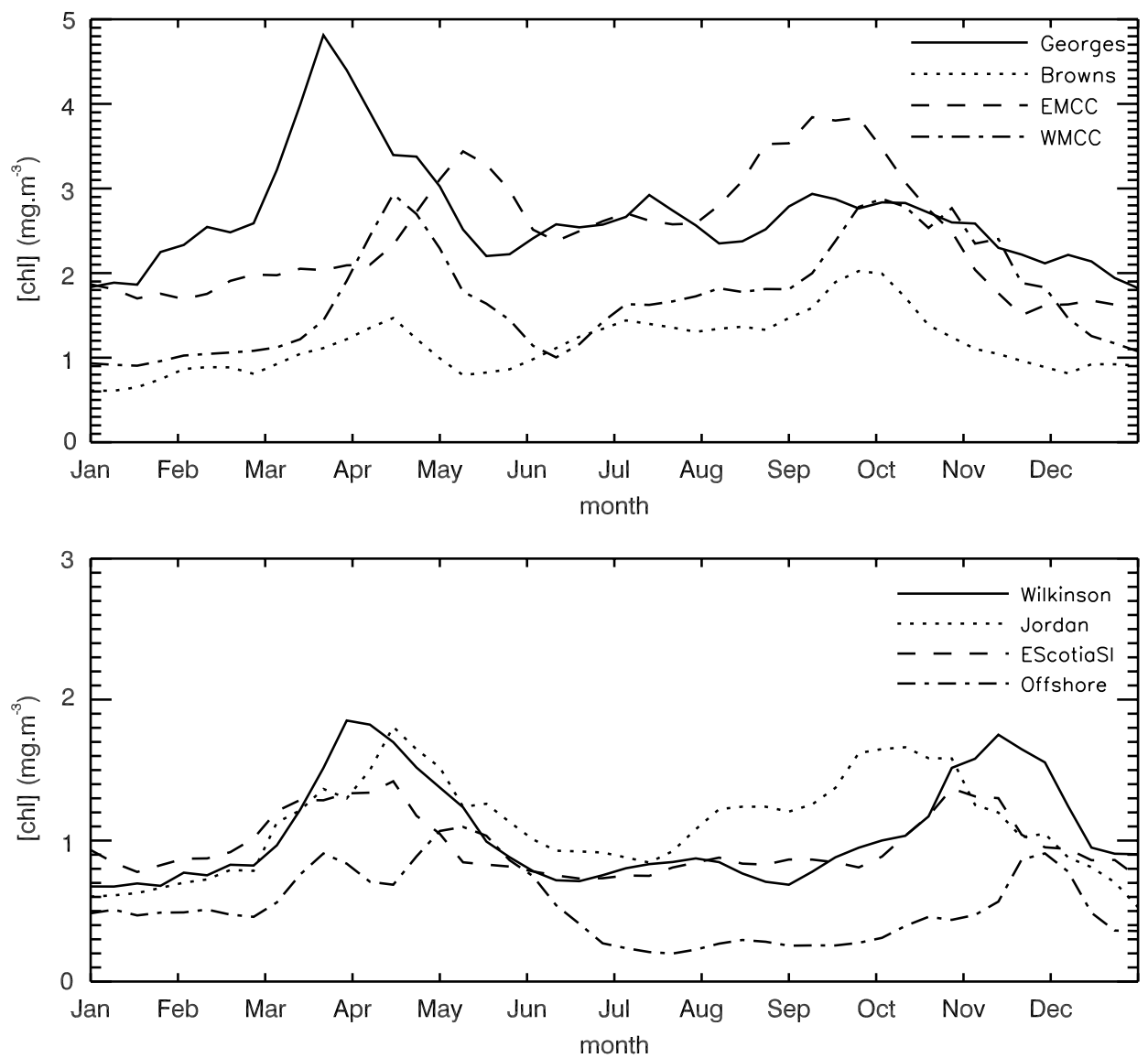

Fig. 3. The 4-year (1997-2001) mean seasonal cycle of chlorophyll concentration $\left(\mathrm{mg} \mathrm{m}^{-3}\right)$ at eight locations (see Fig. 1) sampled from 8-day climatological SeaWiFS composite images.

Over the Scotian Shelf, concentrations are generally lower than those within the Gulf of Maine, elevated concentrations are more closely restricted to the coast and both the spring and fall blooms are weaker. From June through October, a tongue of relatively low chlorophyll concentration separates high concentrations immediately adjacent to the southwestern Nova Scotia coast from high concentrations further offshore near the $100 \mathrm{~m}$ isobath. Elevated chlorophyll concentrations along a shelf-break front south of Georges Bank shown by Ryan et al. (1999) in spring data are temporally/spatially persistent enough to be present in the climatological data (March-May) and are also shown here to be present in the fall (October).

Fig. 3 quantifies differences in the seasonal cycle at 8 locations (Fig. 1) within the study area using the increased temporal resolution afforded by climatological 8-day composites. High concentrations on Georges Bank are present over the entire year, with winter $\left(1.8-2.5 \mathrm{mg} \mathrm{m}^{-3}\right.$, DecemberFebruary) and spring $\left(4.8 \mathrm{mg} \mathrm{m}^{-3}\right.$, late March) concentrations the highest of the sites examined.

Fig. 2. Climatological (September 1997-August 2001) monthly composites of SeaWiFS chlorophyll concentration in the Gulf of Maine showing spatial patterns associated with the mean annual cycle. 
The spring increase begins in late January, peaks at the end of March and ends in mid-May, but a pronounced fall bloom is absent. Each of the other locations exhibit both a clear spring and fall maximum. Initiation of the climatological spring bloom begins earliest over Georges Bank (late January), and latest in the Western (mid-March) and Eastern Maine Coastal Currents (early April). At other sites, the spring increase begins in early March. Time of peak spring concentrations parallel this phasing. They occur earliest over Georges Bank and progressively later over Wilkinson Basin (late March), Jordan Basin, east Scotian Shelf, Western Maine Coastal Current, Browns Bank (mid-April) and latest within the Eastern Maine Coastal Current (early May). Distinct differences are evident in both the timing and the duration of the fall increase, that peaks in September in the EMCC, in early October over Jordan Basin, Browns Bank and the WMCC, but progressively later over the east Scotian Shelf (late October), Wilkinson Basin (mid-November) and offshore (late November).

\subsection{Interannual variability}

The time series of monthly composites over the 4 years of SeaWiFS coverage is shown in Fig. 4, allowing direct comparison of interannual differences in patterns. Large-scale features evident in the climatological seasonal cycle are present in each year, but distinct interannual differences in spatial extent, concentrations and timing are evident. Winter (January, February) interannual variability is relatively weak but increased concentrations in the western Gulf and the EMCC region are evident in 1999 and 2001. Spring data (March-May) document differences in the timing, magnitude and spatial extent/position of the spring bloom. In 1998, the spring bloom developed first (March) over the shelfbreak outside the Gulf of Maine and then moved into the Gulf of Maine and onto the inner Scotian Shelf in April with relatively low peak concentrations and a spatial pattern strongly related to published surface circulation patterns (e.g. Xue et al., 2000) suggesting strong advective control. By May, regions over Wilkinson and Jordan Basins in the Gulf as well as the entire Scotian Shelf had returned to low concentrations. In 1999, the spring bloom is strong in March over the Scotian Shelf, Georges Bank and eastern portions of the Gulf of Maine but switches in April to the western Gulf of Maine. The 2000 spring bloom period shows April maxima over both the central Scotian shelf, western Gulf of Maine and the shelfbreak region. The spatial extent of high concentrations during the 2001 spring bloom is the largest in the 4-year data set with a simultaneous April peak in the eastern and western basins of the Gulf of Maine and the Scotian Shelf. This year is also characterized by strong chlorophyll concentrations in the shelfbreak front region which begin in March off Nova Scotia and continue off Georges Bank in both April and May.

The summer decrease in concentrations over deeper basins within the Gulf and over the Scotian Shelf is relatively weak in June 2000 and July August 1999. The fall increase in concentrations is strongest and most spatially extensive in 1999 (October, November) including each of the major basins within the Gulf as well as the entire Scotian Shelf, consistent in timing to data shown by Fournier et al. (1984a). These authors show that interannual variability in vertical stratification in late fall can modulate chlorophyll concentrations on the Scotian Shelf. The fall increase is relatively weak, peaks early (September) and is primarily over the eastern Gulf in 1997 and peaks later (October-November) and over the western Gulf in 1998. Except in 1999, the fall increase is weakest over the deep basins within the Gulf and over the Scotian Shelf, although clouds prevent examination of patterns in November-December 2000.

Time series at eight locations (see Fig. 1) highlight interannual variability in major seasonal features (Fig. 5). The relatively weak 1998 concentrations evident in Fig. 4 are clearly evident at most locations and persist throughout the year. These 8-day data improve the temporal resolution of seasonal features evident in Fig. 4, showing the spring bloom to be relatively late in 2001 and relatively early in 1999 at most locations but variable in both timing and peak concentration in each location/year. Differences in the timing, duration and magnitude of the fall bloom show 


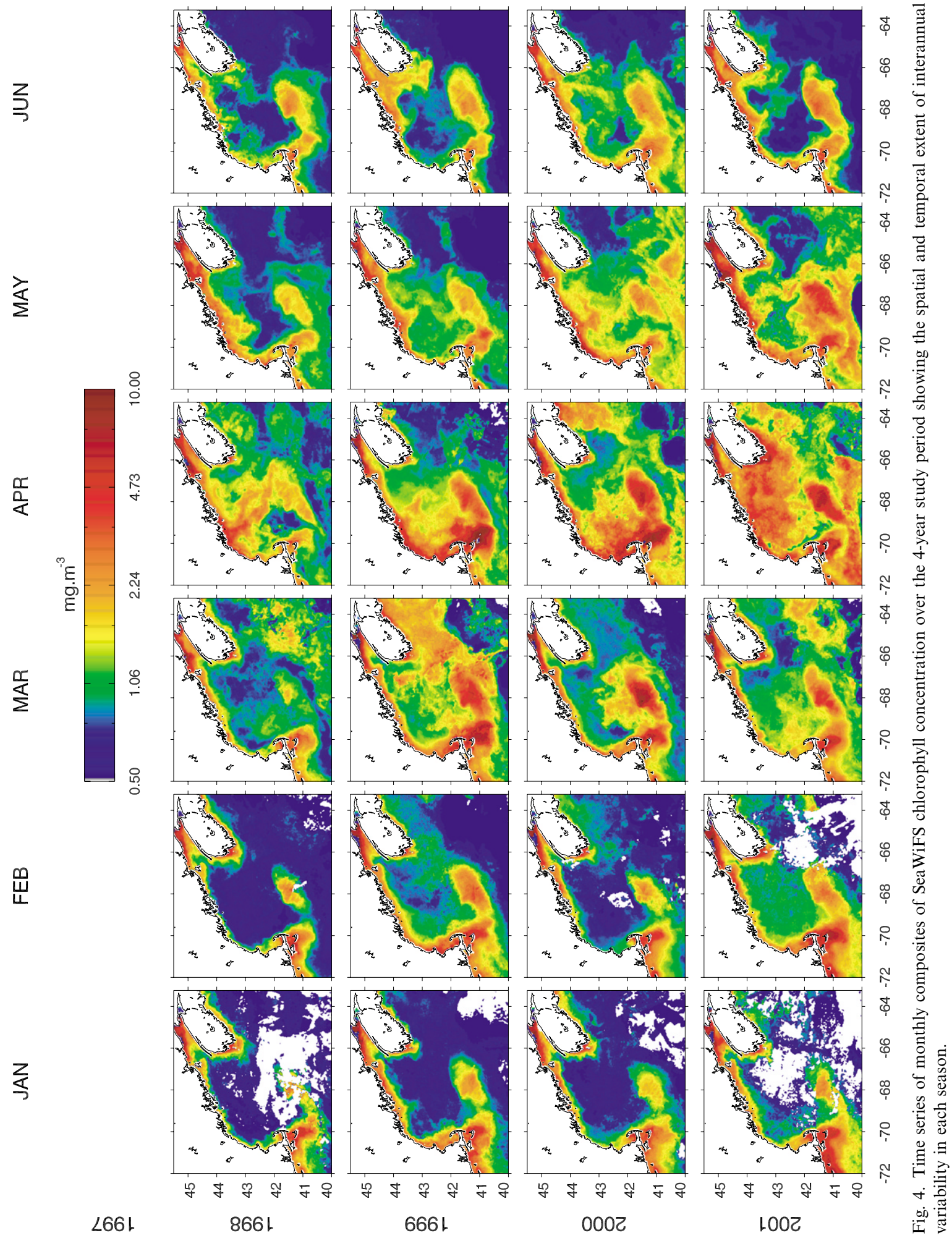



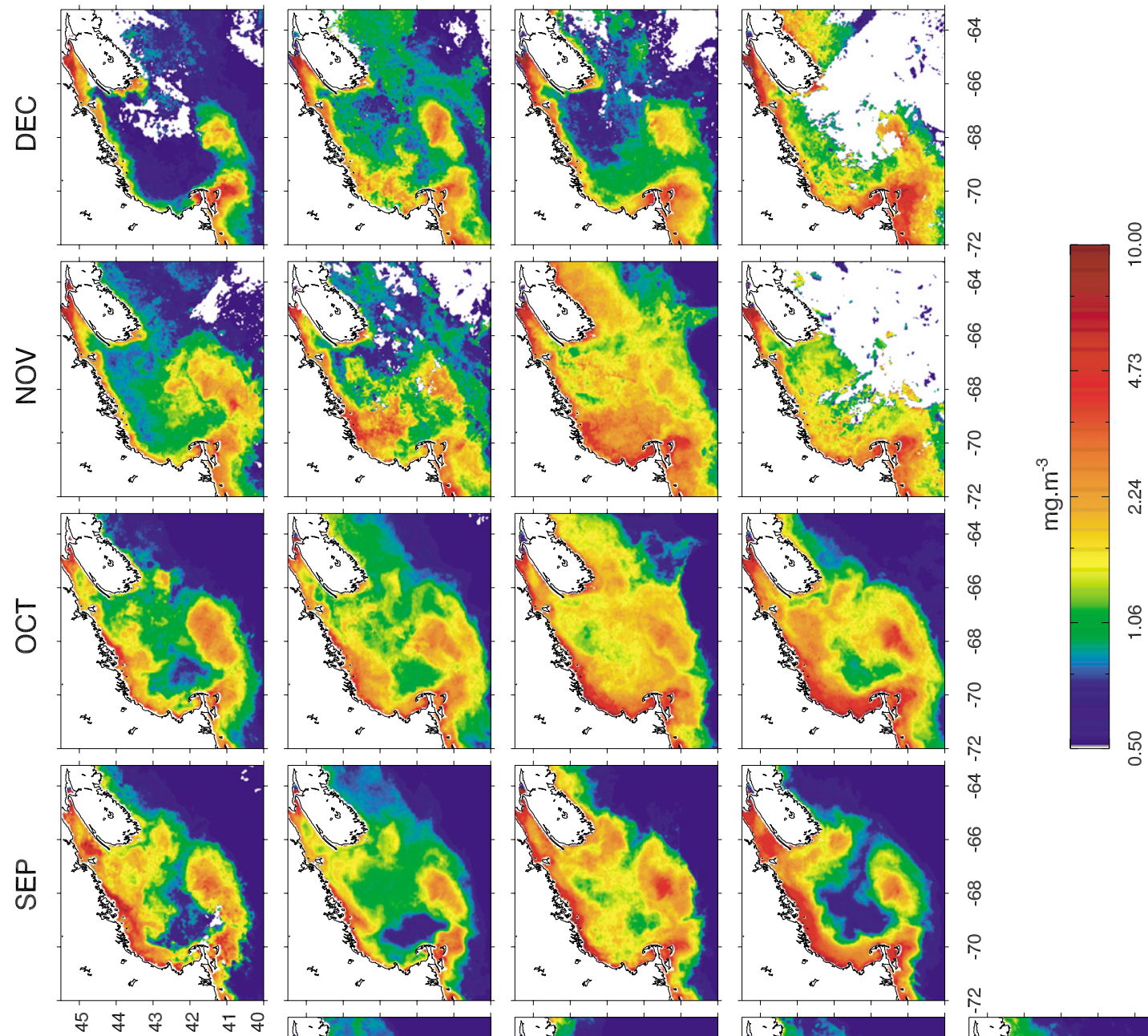

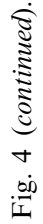

$\stackrel{0}{2}$
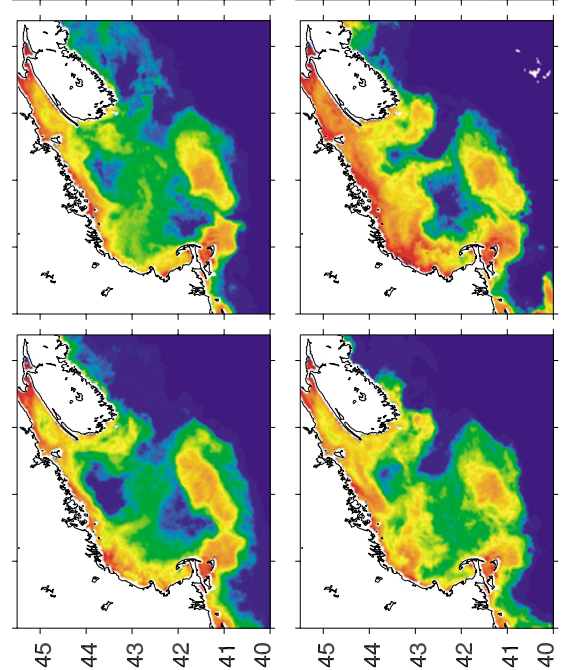

$\angle 661$

866 t

666 เ
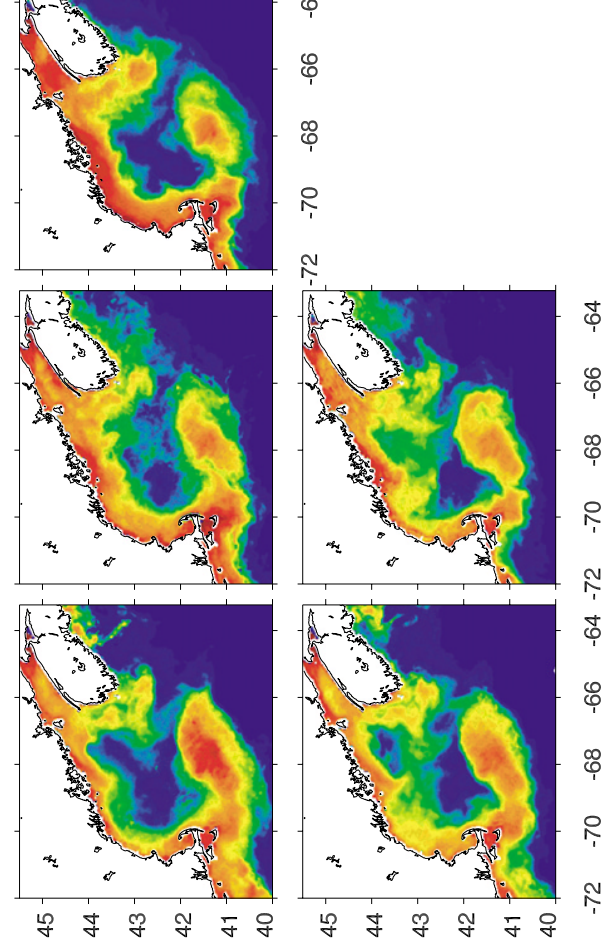

0002

1002 


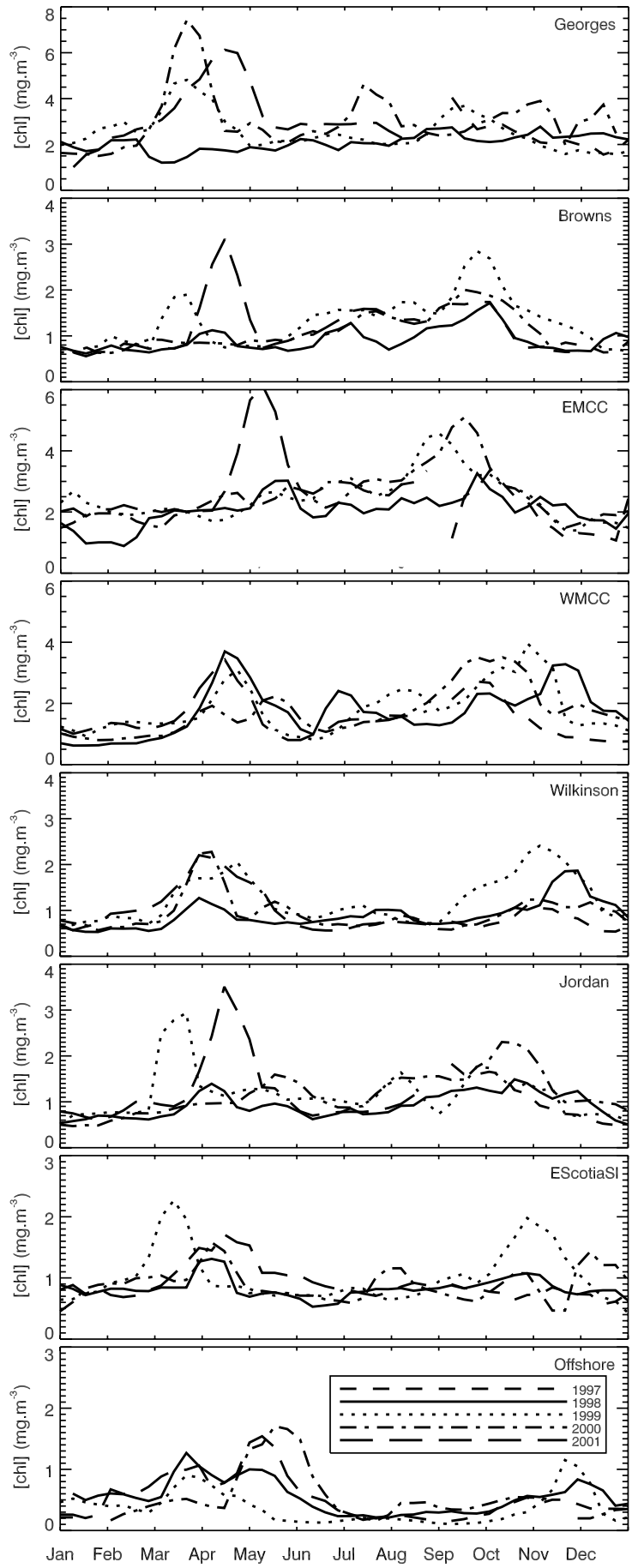

Fig. 5. Four years of SeaWiFS chlorophyll concentration $\left(\mathrm{mg} \mathrm{m}^{-3}\right)$ sampled from a time series of 8-day composites at eight locations (see Fig. 1) showing interannual variability in timing and magnitude of major seasonal features.
1999 and/or 2000 to be relatively strong and early at many locations. One consistent feature is the late fall peak in 1998 over Browns Bank, EMCC, WMCC, Wilkinson and Jordan Basins and at the offshore location. These data also highlight the extent to which the climatological seasonal cycles calculated from these 4 years (Fig. 3) are biased by interannual variability.

Dominant time/space patterns of chlorophyll variability over the study area during the 4 years are summarized quantitatively using an empirical orthogonal function (EOF) decomposition of the 48 month image time series. Prior to EOF calculation, the climatological mean of each location was subtracted, removing the temporal mean from each pixel location. Missing data ( $<6 \%$ of the total data matrix, overwhelmingly in winter months) were flagged but not filled. Results of this EOF analysis (Fig. 6) partition the chlorophyll variance into a series of orthogonal modes, each having a spatial pattern modulated by an associated time series, which explain a decreasing percentage of the total variance present in the space/time series. The first mode $(28.8 \%$ of the variance) shows concentrations over most of the study region varying in phase, strongest on top of Georges Bank, Nantucket Shoals and the northern side of the Bay of Fundy and weakest (or slightly negative) over the outer edges of the EMCC region, the southern Bay of Fundy and the frontal region surrounding Georges Bank. The time series associated with this spatial pattern is dominated by the seasonal cycle, quantifying interannual variability especially in the spring and fall blooms. These are weakest in fall 1997 and in spring and fall of 1998 but relatively strong through the rest of the time series. Summer concentrations are strongest in 2000 . The second mode $(19.6 \%$ of the variance) also shows most of the Gulf of Maine varying in phase. Exceptions are the central core of the EMCC, the northern Bay of Fundy and shallow coastal regions on the western Scotian Shelf. The positive pattern shows maxima closely associated with the central and southern Maine coast and extending out over Jordan Basin and the outer edge of the southern Scotian Shelf. The negative pattern is maximum over Nantucket Shoals, south of Cape Cod and in the upper Bay 

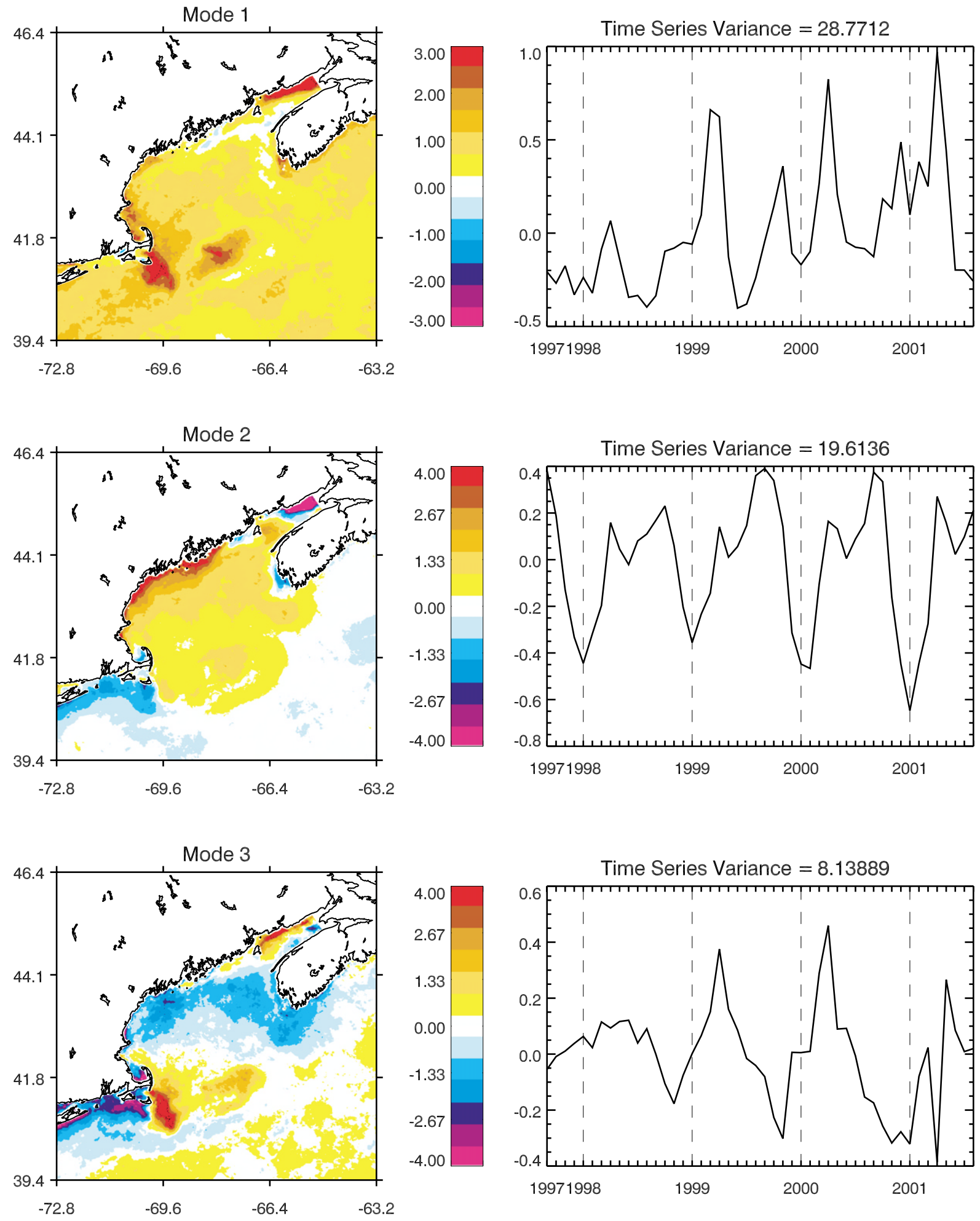
of Fundy, consistent with the out of phase seasonality between the Gulf of Maine and the shelf farther south calculated by Yoder et al. (2002). The time series for this pattern shows strong winter maxima for the negative portions of the spatial pattern (maximum in January of each year, strongest in 2001) and elevated chlorophyll concentrations spring through fall over the Gulf of Maine in the positive portion of the spatial pattern. The spring-fall modulation shows a submaximum in April of each year and a second broader maximum in fall, each of which augment the bloom patterns of Mode 1. Interannual variability in this mode is relatively weak, however, a relatively weak fall maximum in 1998 is evident. The spatial pattern associated with the third mode ( $8.1 \%$ of the variance) shows negative maxima over the New England Bight and in a broad region beginning in the coastal western Gulf of Maine and extending across Jordan Basin to include the southern Scotian Shelf and Browns Bank area. Positive maxima are over Nantucket Shoals, Georges Bank and the northern Bay of Fundy. The temporal modulation of these patterns shows the negative pattern to be an augmentation of the fall bloom with a maximum in November, weakest in 1997 and 1998. The positive pattern is an augmentation of the spring bloom, maximum in April and again weaker in 1998.

\section{Discussion}

The seasonality of chlorophyll concentrations over the study area generally follow a canonical North Atlantic annual cycle with a winter minimum, spring bloom, a mid-summer decrease followed by a fall bloom. The amplitude and timing of this pattern are modulated by differences induced by vertical mixing over shallow bathymetry, stratification induced by freshwater in the coastal zone and residual circulation. Satellitemeasured timing of the spring bloom over Browns
Bank (Fig. 3) is consistent with in situ data for the southwest Scotian Shelf (Perry et al., 1989). These authors show the bloom peak to vary between late March and mid-April for the period 1983-1985. Fig. 2 shows that elevated chlorophyll concentrations remain through summer (June-August) surrounding Jordan Basin, consistent with residual circulation advecting phytoplankton and nutrientrich coastal current water out over the deeper central Gulf. In fall, elevated concentrations associated with the bloom develop latest over deeper, more strongly stratified regions of Wilkinson Basin. Over shallow banks, concentrations remain high throughout the year as a result of nutrient flux from tidal mixing (and possible resuspended sediment). In these locations, the spring bloom develops relatively early, consistent with spring in situ data from Georges Bank (Townsend and Thomas, 2001) that show increasing chlorophyll concentrations and nutrient utilization as early as February or even January (Townsend and Thomas, 2002). In these regions, bathymetry restricts the depth of vertical mixing, reducing light limitation and allowing the spring bloom to begin early (Townsend et al., 1994). Along the coast of Maine, strong vertical mixing throughout the year in the EMCC brings nutrients to the surface (Townsend et al., 1987) supporting elevated chlorophyll concentrations that are advected southwest along the coast, with maximum concentrations developing offshore of the Penobscot Bay region near the terminus of the strongest flow (Figs. 2, 4 and 6).

The clearest features of interannual variability evident in Figs. 4 and 6 are relatively low chlorophyll concentrations in (late) 1997 and 1998, especially during spring and fall. Coincident SST fields and their EOF decomposition (not shown) are strongly dominated by a relatively simple sinusoidal seasonal cycle, consistent with those shown by Bisagni et al. (2001). The seasonal cycle was removed by subtracting the climatological (1997-2001) month from individual months

Fig. 6. Three strongest modes (56.5\% of the total variance) of an empirical orthogonal function (EOF) decomposition of the 48 month SeaWiFS image time series from Fig. 4 showing spatial patterns of mode strength and (b) the temporal modulation of each pattern over the 4-year period. 

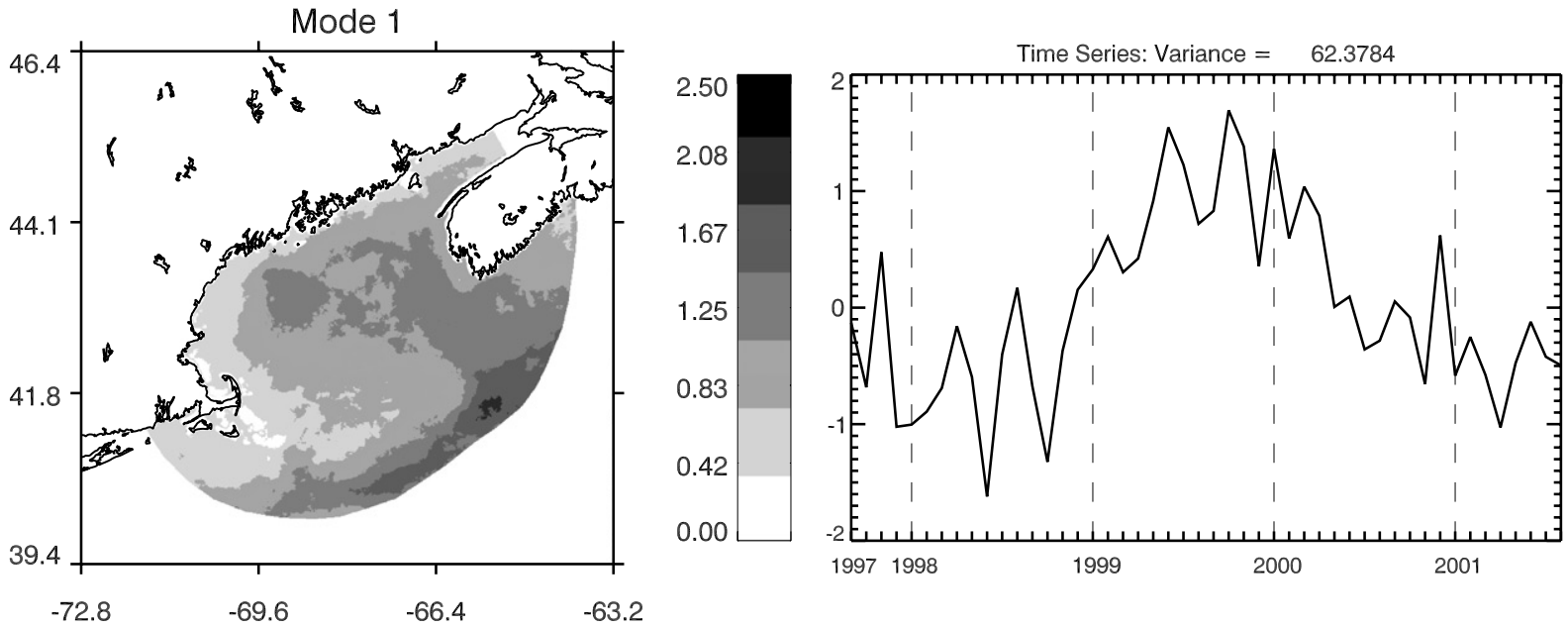

Fig. 7. The dominant mode (62.4\% of the variance) of an EOF decomposition of the 48-month satellite SST anomaly fields over the Gulf of Maine coincident with the SeaWiFS data (September 1997-August 2001). The EOF shows the spatial pattern and the time series modulation of this pattern.

allowing SST anomalies to highlight interannual variability. Fig. 7 shows the dominant mode (62.4\% of the variance) of an EOF decomposition of the 48 month SST anomaly fields coincident with the SeaWiFS time series. The spatial pattern shows coincident anomalies over the entire region, maximum over the deeper, shelfbreak regions where the influence of slope water is strongest. Within the Gulf, maximum strength is over the Northeast Channel, the outer edge of the southern Scotian Shelf and immediately south of Penobscot Bay, consistent with areas expected to have the strongest bottom water connection to slope water influence. Examination of the time series shows that 1998 was characterized by months of relatively cold SSTs during the winter-early spring of 1997-1998 and again in summer and fall. The general trend is of lowest values early in the series, increasing after October 1998 to maximum values in 1999 and then decreasing again after April 2000. The cold anomalies from December 1997 to March 1998 are the most continuous period of strong negative anomalies in the record and the two cold anomalies in the summer and fall are the strongest in the time series. These early cold anomalies are coincident with the weakest spring and fall chlorophyll blooms in the 4-year SeaWiFS chlorophyll record. One potential biological link is through decreased vertical stability and resulting light limitation. This is consistent with reduced spring concentrations but not necessarily with reduced fall biomass.

The extent to which interannual variability evident in the SeaWiFS chlorophyll time series and the SST anomalies are associated with local wind forcing is examined using coincident hourly buoy data from a site within the Gulf (Fig. 1). Anomalies of 8-day average wind mixing strength, characterized as $\mathrm{U}^{* 3}$, over the study period were formed by subtracting the 12-year mean (19902001). The anomaly time series of wind mixing in each year (Fig. 8) show the expected maximum anomalies during the fall-winter-spring period of increased storm activity with smaller anomalies through the summer months. A consistent relationship between wind mixing and SST anomalies (Fig. 7) through an annual cycle is not expected. The satellite data measure surface skin temperatures. In the Gulf of Maine, strong and seasonally reversing air/sea temperature gradients mean that the relationship between wind mixing and SST likely switches between winter and summer. In winter, strong mixing would bring relatively warm deeper water to the surface preventing the formation of very cold SSTs, resulting in warm anomalies. In summer, strong mixing would bring colder subsurface water to the surface, weakening stratification and creating cold anomalies. In 


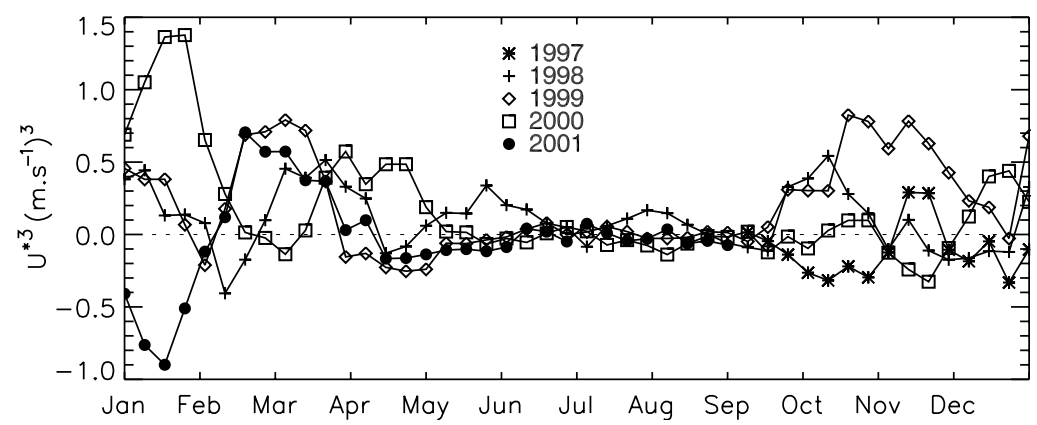

Fig. 8. Interannual variability in wind mixing, characterized as anomalies of 8 -day averaged $\mathrm{U}^{* 3}\left(\times 10^{-6}\right)$, in the Gulf of Maine over the 4-year study period. Anomalies were formed by subtracting the 12-year (1990-2001) mean from each 8-day period. Location of the NOAA buoy is shown in Fig. 1.

spring and fall, during the transition between these two extremes, the net effect will depend on present and previous local conditions. Summer wind mixing anomalies in Fig. 8 are largest and positive in 1998, the year of coldest summer SST anomalies. Maximum wind mixing in October 1999January 2000 is coincident with warmer winter SST anomalies and the negative wind anomalies of October and December 1997 and January 2001 are coincident with strong negative SST anomalies. The relationship of both SST and wind forcing to chlorophyll variability is through stratification and its role in light limitation and vertical nutrient flux into the euphotic zone. The weak spring bloom of 1998 (Fig. 6, Modes 1 and 3), although associated with cold winter SST anomalies, is not clearly associated with spring wind anomalies different from the other 3 study years. Increased summer wind forcing in 1998 might lead to increased vertical nutrient flux, but 1998 chlorophyll concentrations are relatively low. Similarly, strong April 2000 wind forcing might be expected to delay or reduce the spring bloom, but a strong chlorophyll maximum is present.

In the absence of a clear relationship between local wind forcing and interannual variability of overall phytoplankton biomass, we examine potential links to basin-scale processes and local hydrography that are consistent with the chlorophyll time series. Previous authors have shown a link between the North Atlantic Oscillation (NAO), hydrographic properties along the northeastern Atlantic shelf slope, the Gulf of Maine and zooplankton data within the Gulf. Pickart et al.
(1999) isolate two distinct modes of slope water variability off Atlantic Canada; a maximum during which Labrador Sea Water input to the Deep Western Boundary Current is enhanced but transport of the Labrador Current and Labrador Subarctic Slope Water along the continental slope are reduced, and a minimum during which the Deep Western Boundary Current has less Labrador Sea Water but transport of Labrador Subarctic Slope Water along the continental shelf are enhanced. The maximum mode allows Atlantic Temperate Slope Water to move inshore as the Labrador Subarctic Slope Water shifts north. These authors suggest that the maximum (minimum) mode appears to be associated with the positive (negative) phase of the NOA. Pershing et al. (2001) and Drinkwater et al. (in press) show that such a shift in NAO/slope water mode occurred in 1996-1997, influencing the hydrography of the Gulf of Maine. During the winter of 1996-1997, the NAO index became strongly negative and Labrador Subarctic Slope Water moved southward along the Scotia Shelf and penetrated into deeper basins of the Gulf of Maine through the Northeast Channel. They show that by May 1998, it had replaced deeper waters of Georges Basin and by September/October it had penetrated into Wilkinson and Jordan Basins. By 1999, however, the NAO had shifted back to positive, the slope water at the entrance to the Northeast Channel had switched back to warmer, more saline Atlantic Temperate Slope Water and hydrographic anomalies in the Gulf of Maine basins disappeared. Fig. 9 shows the monthly 


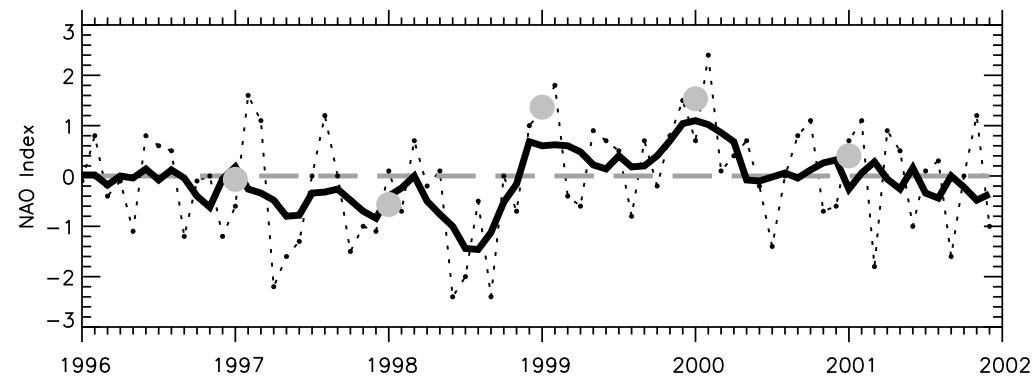

Fig. 9. The NOAA Climate Prediction Center monthly North Atlantic Oscillation (NAO) Index for the 6-year period beginning January 1996. The dashed line shows monthly average values, the solid line is a 5 month running mean and the circle symbols show the winter (mean of December, January and February) NAO index.

NAO index for the period 1996-2001 calculated by the NOAA Climate Prediction Center, as well as the winter value (mean of December, January, February) for the study period. These data show the strongly negative values early in the SeaWiFS study period and the abrupt shift to positive values in late 1998. Winter NAO indices for 1998-1999 and 1999-2000 are both strongly positive. Thereafter, the index decreases slowly to a weak positive winter index in 2000-2001, with the 5 month running mean turning weakly negative by mid2001.

At least 2 mechanisms can be postulated that would link interannual variability of deepwater properties to the surface chlorophyll interannual variability presented here. Townsend et al. (1987) have argued that the overall nutrient budget for the Gulf of Maine is strongly controlled by deepwater input through the Northeast Channel. The connection between deepwater nutrient concentrations and surface availability to phytoplankton is through strong vertical mixing, especially in the Eastern Maine Coastal Current (Townsend et al., 1987). Changes in $\mathrm{T} / \mathrm{S}$ properties of slope water at the entrance of the Northeast Channel associated with the NAO time series shown by Pershing et al. (2001) and Drinkwater et al. (in press) are consistent with our own data from a hydrographic station within the Northeast Channel (see Fig. 1) in 1997, 1998 and 1999. Vertical profiles from March (Fig. 10) show a colder, less saline water mass at mid-depths $(\sim 30-150 \mathrm{~m})$ in 1998 than was present in either 1997 or 1999. Nutrient concentrations (Fig. 10) show this cold, less saline water mass is associated with strongly reduced nitrate/nitrite and silicate concentrations. This suggests that the vertical flux of subsurface water within the Gulf of Maine over the year, especially within the EMCC region and over shallow bathymetry, would support reduced phytoplankton biomass. A second mechanism is consistent with the argument (Townsend and Spinrad, 1986) that upward doming of dense deep water and the subsequent formation of a pycnocline at depths shallower than the critical depth is one mechanism by which the spring bloom can be initiated over deeper basins of the Gulf of Maine. In both 1997 and 1999, the relatively warm, saline subsurface water creates a pycnocline and vertical stability within the upper $75 \mathrm{~m}$ of the water column assisting initiation of the spring bloom. By March, surface nutrient concentrations are reduced and in situ chlorophyll concentrations were 4.4 and $6.4 \mathrm{mg} \mathrm{m}^{-3}$ (average of 2 and $20 \mathrm{~m}$ ) in 1997 and 1999 respectively. In contrast, lack of upper water column stability in March 1998 was capable of delaying or reducing the spring bloom, with elevated near-surface nutrient concentrations still present (Fig. 10) and upper water column chlorophyll concentrations of $1.5 \mathrm{mg} \mathrm{m}^{-3}$ (2 and $20 \mathrm{~m}$ average).

Decreased chlorophyll concentrations in 1998 resulting from NAO-linked hydrographic changes also provide a consistent explanation for observed interannual variability in Gulf of Maine zooplankton. Conversi et al. (2001) and Pershing et al. (2001) both show that the NAO is positively correlated with changes in zooplankton (Calanus finmarchicus) abundance at lags of 3-4 years. The lag suggests to the authors that zooplankton 

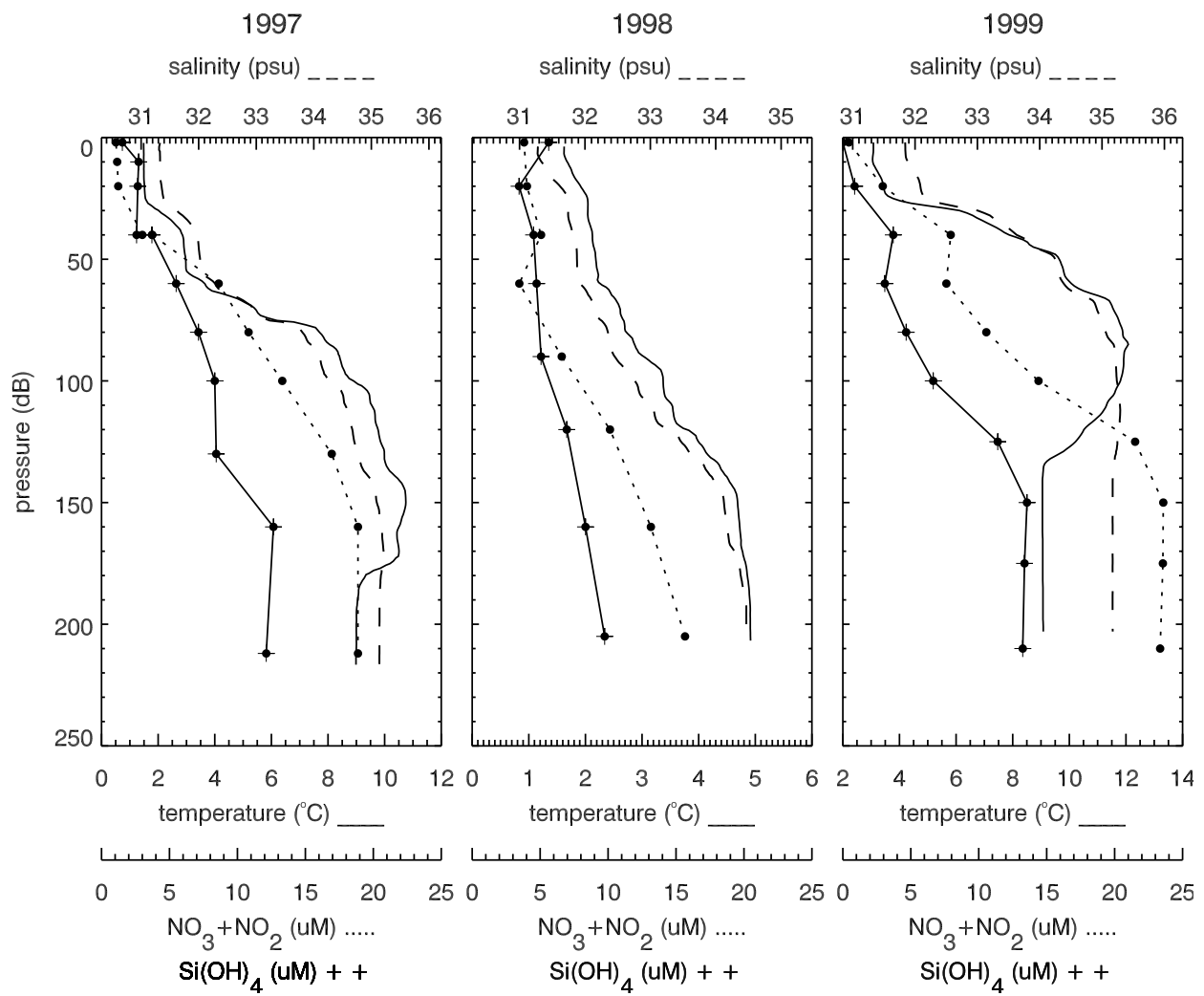

Fig. 10. Vertical profiles of temperature, salinity, nitrate/nitrite and silicate at a station in the Northeast Channel (see Fig. 1), in March 1997-1999, showing interannual differences in mid-depth $(50-150 \mathrm{~m})$ and surface hydrographic and nutrient properties linked to changes in slope water intrusions into the Gulf. Bottle depths are marked on the nutrient profiles.

biomass decreases in negative NAO years are largely a result of changes in transport. If the relationship shown here for 1997-1999 are consistent over decadal time scales of NAO changes, then decreased zooplankton survival and/or growth and reproduction rates resulting from low phytoplankton biomass during negative NAO years provides an additional, trophic, linkage to basin-scale forcing.

\section{Conclusions}

The first 4 years of data from the SeaWiFS mission provide the first synoptic quantification of seasonal and interannual variability of chlorophyll concentrations over the Gulf of Maine. Mean seasonal variability follows general patterns expected from previously published work based on more sparsely sampled in situ data. Except along coastal margins and shallow banks, winter concentrations are low. There is a spring bloom followed by a mid-summer decrease and then a fall bloom, usually of more prolonged duration and reduced amplitude than the spring bloom. Spatial patterns in the seasonal cycles of chlorophyll are strongly controlled by the interaction of tidal mixing, bathymetry and residual circulation with the strongest seasonal cycles evident over deeper basins.

Interannual variability is apparent in most subregions of the study area, in actual chlorophyll concentrations and/or timing and duration of specific seasonal features. The strongest signal evident in the interannual comparison is reduced concentrations in 1998, especially during the spring and fall blooms. Direct connections to variability in local wind forcing were not evident. 
The reduced concentrations in 1998, however, are coincident with satellite-measured negative surface temperature anomalies and with published reports of cold, low salinity hydrographic anomalies imposed on deeper basins of the Gulf of Maine by changes in water mass properties along the adjacent continental slope associated with the NAO. Coincident in situ data from the Northeast Channel show reduced springtime stratification in the upper water column as well as reduced nutrient concentrations within the intruding subsurface water in 1998. These data suggest that basin-scale forcing associated with the NAO, through its influence on hydrographic structure, has the potential to induce interannual variability in phytoplankton dynamics in the Gulf of Maine.

The Gulf of Maine lies at the geographic boundary for many marine organisms (Sinclair et al., 1992); the southern extreme for many subarctic species and the northern extreme for many temperate species. Relatively small oceanographic anomalies have the potential to cause changes in either overall biomass, the timing of seasonal progression, species distribution, and/or shifts in the local dominance hierarchy. The 4-year time series analyzed here provides a preliminary quantification of synoptic phytoplankton biomass variability. A longer time series as well as improvements in our ability to quantify chlorophyll concentrations in these optically complex coastal waters are prerequisites for improved monitoring and understanding of this heterogeneous marginal sea.

\section{Acknowledgements}

This work was funded by NASA Grants NAG56558 and NAG5-10620 (A.C.T.). We thank Fei Chai, Neal Pettigrew and Huijie Xue for many discussions on Gulf of Maine dynamics, J.E. O'Reilly (NOAA) and B. Balch (Bigelow Laboratory) for continual interaction on ocean color issues in the Gulf of Maine and the NASA Goddard SeaWiFS team for their continual and professional data support. Wind data and the NAO index are made available by NOAA. In situ data were collected as part of the US GLOBEC program.

\section{References}

Bigelow, H.B., 1927. Physical oceanography of the Gulf of Maine. Bulletin of the Bureau Fisheries 40, 511-1027.

Bisagni, J.J., Gifford, D.J., Ruhsam, C.M., 1996. The spatial and temporal distribution of the Maine Coastal Current during 1982. Continental Shelf Research 16, 1-24.

Bisagni, J.J., Seeman, K.W., Mavor, T.P., 2001. High-resolution satellite-derived sea surface temperature variability over the Gulf of Maine and Georges Bank region, 1993-1996. Deep-Sea Research II 48, 71-94.

Brooks, D.A., 1985. Vernal circulation in the Gulf of Maine. Journal of Geophysical Research 90, 4687-4705.

Brooks, D.A., Townsend, D.W., 1989. Variability of the coastal current and nutrient pathways in the eastern Gulf of Maine. Journal of Marine Research 47, 303-321.

Conversi, A., Piontkovski, S., Hameed, S., 2001. Seasonal and interannual dynamics of Calanus finmarchicus in the Gulf of Maine with reference to the North Atlantic Oscillation. Deep-Sea Research II 48, 519-530.

Drinkwater, K.F., Mountain, D.B., Herman, A., Variability in the slope water properties off eastern North America and their effects on the adjacent shelves. Journal of Geophysical Research, in press.

Eslinger, D.L., O'Brien, J.J., Iverson, R.L., 1989. EOF analysis of cloud contaminated coastal zone color scanner images of northeastern North American coastal waters. Journal of Geophysical Research 94, 10884-10890.

Fournier, R.O., Ernst, R., Hargraves, N.B., Van Det, M., Douglas, D., 1984a. Variability of chlorophyll a off southwestern Nova Scotia in late fall and its relationship to water column stability. Canadian Journal of Fisheries and Aquatic Science 41, 1730-1738.

Fournier, R.O., Van Det, M., Hargraves, N.B., Wilson, J.S., Clair, T.A., Ernst, R., 1984b. Physical factors controlling summer distribution of chlorophyll off southwestern Nova Scotia. Limnology and Oceanography 29, 517-526.

Garrett, C.J., Keeley, J.R., Greenberg, D.A., 1978. Tidal mixing versus thermal stratification in the Bay of Fundy and Gulf of Maine. Atmosphere-Ocean 16, 403-423.

Herman, A.W., Sameoto, D.D., Shunnian, C., Mitchell, M.R., Petrie, B., Cochrane, N., 1991. Sources of zooplankton on the Nova Scotia shelf and their aggregations within deepshelf basins. Continental Shelf Research 11, 211-238.

Horne, E.P.W., Loder, J.W., Harrison, W.G., Mohn, R., Lewis, M.R., Irwin, B., Platt, T., 1989. Nitrate supply and demand at the Georges Bank tidal front. In: Ros, J.D. (Ed.), Topics in Marine Biology, Vol. 53. Bedford Institute of Oceanography, Scientifica Marina, pp. 145-158.

Jossi, J.W., Smith, D.E., 1989. Continuous Plankton Records: Massachusetts to Cape Sable, N.S. and New York to the Gulf Stream, 1988. NAFO SCR Doc. 89/59. 
Jossi, J.W., Smith, D.E., 1990. Continuous Plankton Records: Massachusetts to Cape Sable, N.S. and New York to the Gulf Stream, 1989. NAFO SCR Doc. 90/66.

O'Reilly, J.E., Busch, D.A., 1984. Phytoplankton primary production on the northwestern Atlantic shelf. Rapports et Proces Verbaux des Reunions Conseil International pour l'Exploration de la Mer 183, 255-268.

O'Reilly, J.E., Zetlin, C., 1996. Monograph on the seasonal, horizontal and vertical distribution of phytoplankton chlorophyll $a$ in the northeast US continental shelf ecosystem. NOAA Technical Report 139, Fishery Bulletin, National Marine Fisheries Service.

O’Reilly, J.E., Evans-Zetlin, C., Busch, D.A., 1987. Primary production. In: Backus, R.H. (Ed.), Georges Bank. MIT Press, Cambridge, MA, pp. 221-233.

O'Reilly, J.E., Maritorena, S., Mitchell, B.G., Seigal, D., Carder, K., Garver, S., Kahru, M., McClain, C., 1998. Ocean color chlorophyll algorithms for SeaWiFS. Journal of Geophysical Research 103, 24937-24954.

Perry, R.I., Hurley, P.C.F., Smith, P.C., Koslow, J.A., Fournier, R.O., 1989. Modeling the initiation of spring bloom biomass: a synthesis of physical and biological variability off southwest Nova Scotia 1983-85. Canadian Journal of Fisheries and Aquatic Science 46, 183-199.

Pershing, A.J., Greene, C.H., Hannah, C., Sameoto, D., Head, E., Mountain, D., Jossi, J., Benfield, M.C., Reid, P.C., Durbin, T.G., 2001. Oceanographic responses to climate in the Northwest Atlantic. Oceanography 14, 76-82.

Pettigrew, N.R., Townsend, D.W., Xue, H., Wallinga, J.P., Brickley, P.J., Hetland, R.D., 1998. Observations of the Eastern Maine Coastal Current and its offshore extensions. Journal of Geophysical Research 103, 30623-30640.

Pickart, R.S., McKee, T.K., Torres, D.J., Harrington, S.A., 1999. Mean structure and interannual variability of the slopewater system south of Newfoundland. Journal of Physical Oceanography. 29, 2541-2558.

Riley, G.A., 1941. Plankton studies. IV. Georges Bank. Bulletin of the Bingham Oceanographic Collection 7, 1-73.

Riley, G.A., 1947. Seasonal fluctuations of the phytoplankton population in New England coastal waters. Journal of Marine Research 6, 114-127.

Ryan, J.P., Yoder, J.A., Cornillon, P.C., 1999. Enhanced chlorophyll at the shelfbreak of the mid-Atlantic Bight and Georges Bank during the spring transition. Limnology and Oceanography $44,1-11$.

Simpson, J.H., Hunter, J.R., 1974. Fronts in the Irish Sea. Nature 250, 404-406.
Sinclair, M., Wilson, S., Subba Rao, D.V., 1992. Overview of the biological oceanography of the Gulf of Maine. In: Wiggins, J., Mooers, C.N.K. (Eds.), Proceeding of the Gulf of Maine Workshop.

Townsend, D.W., Spinrad, R.W., 1986. Early spring phytoplankton blooms in the Gulf of Maine. Continental Shelf Research 6, 515-529.

Townsend, D.W., Pettigrew, N.R., 1997. Nitrogen limitation of secondary production on Georges Bank. Journal of Plankton Research 19, 221-235.

Townsend, D.W., Pettigrew, N.R., Thomas, A.C., 2001. Offshore blooms of the red tide dinoflagellate, Alexandrium sp. in the Gulf of Maine. Continental Shelf Research 21, $347-369$.

Townsend, D.W., Thomas, M.A., 2002. Springtime nutrient and phytoplankton dynamics on Georges Bank. Marine Ecology Progress Series 228, 57-74.

Townsend, D.W., Christensen, J.P., Stevenson, D.K., Graham, J.J., Chenoweth, S.B., 1987. The importance of a plume of tidally-mixed water to the biological oceanography of the Gulf of Maine. Journal of Marine Research 45, 699-728.

Townsend, D.W., Cammen, L.M., Holligan, P.M., Campbell, D.E., Pettigrew, N.R., 1994. Causes and consequences of variability in the timing of spring phytoplankton blooms. Deep-Sea Research I 41, 747-765.

Townsend, D.W., Thomas, A.C., 2001. Winter-spring transition of phytoplankton chlorophyll and inorganic nutrients on Georges Bank. Deep-Sea Research II 48, 199-214.

Xue, H., Chai, F., Pettigrew, N.R., 2000. A model study of seasonal circulation in the Gulf of Maine. Journal of Physical Oceanography 30, 1111-1135.

Yentsch, C.S., Garfield, N., 1981. Principal areas of vertical mixing in the waters of the Gulf of Maine, with reference to the total productivity of the area. In: Gower, J.F.R. (Ed.), Oceanography from Space. Plenum Press, New York, pp. 303-312.

Yoder, J.A., O'Reilly, J.E., Barnard, A.H., Moore, T.S., Ruhsam, C.M., 2001. Variability in coastal zone color scanner (CZCS) chlorophyll imagery of ocean margin waters off the US East Coast. Continental Shelf Research 21, 1191-1218.

Yoder, J.A., Schollaert, S., O'Reilly, J.E., 2002. Climatological phytoplankton chlorophyll and sea surface temperature patterns in continental shelf and slope waters off the northeast US Coast. Limnology and Oceanography 47, 672-682. 